\title{
Optimalisasi teknologi informasi oleh lembaga pemerintah dalam aktivitas komunikasi publik
}

\author{
Centurion Chandratama Priyatna ${ }^{1}$, F.X Ari Agung Prastowo ${ }^{2}$, \\ Fajar Syuderajat ${ }^{3}$, Anwar Sani ${ }^{4}$ \\ 1,2,3,4 Universitas Padjadjaran, Bandung, Indonesia
}

\begin{abstract}
ABSTRAK
Humas di lembaga pemerintahan berperan penting dalam pengelolaan komunikasi publik. Tantangan yang dihadapi dalam pengelolaan komunikasi publik saat ini adalah perkembangan teknologi komunikasi dan derasnya arus informasi yang ada di masyarakat. Lembaga-lembaga pemerintah pusat maupun daerah dituntut untuk mengoptimalkan berbagai bentuk kemajuan teknologi komunikasi dalam pengelolaan komunikasi publik agar kebutuhan masyarakat akan informasi mengenai kebijakan dan program pemerintah bisa disampaikan dengan baik sehingga pada akhirnya dapat memperoleh dukungan yang positif dari masyarakat. Penelitian ini dilakukan untuk mengetahui pengelolaan komunikasi publik pada lembaga pemerintah dengan mengoptimalkan teknologi komunikasi sesuai dengan standar yang tertulis pada Instruksi Presiden No 9 Tahun 2015 tentang pengelolaan komunikasi publik. Penelitian ini menggunakan mix method dengan memadukan data kuantitatif dan kualitatif. Penggunaan mix method dalam penelitian ini diharapkan dapat memenuhi kebutuhan data yang diperlukan secara holistik agar diperoleh gambaran pengelolaan komunikasi publik di Kementerian, Lembaga dan Pemerintah Daerah. Hasil dari penelitian ini adalah mayoritas responden yang terdiri dari tenaga humas Kementerian, Lembaga dan Dinas Kominfo tingkat Provinsi telah melakukan pengelolaan komunikasi publik dengan mengoptimalkan teknologi komunikasi dalam bentuk penyebaran narasi tunggal dan program prioritas pemerintah melalui media online dan media sosial serta melakukan media monitoring dan audit komunikasi sebagai bentuk controlling dan evaluasi. Selain itu, telah dilakukan koordinasi antarlembaga pemerintah dalam pengelolaan komunikasi publik. Rekomendasi yang diberikan oleh peneliti adalah ditingkatkannya kualitas dan kuantitas SDM, infrastuktur komunikasi, melakukan perencanaan strategik yang mengutamakan pada komunikasi interpersonal pada pengelolaan komunikasi publik serta perlu dilakukan penguatan kelembagaan di Lembaga, Kementerian, dan Dinas Komunikasi dan Informatika.
\end{abstract}

Kata-kata Kunci: Humas pemerintah; pengelolaan komunikasi publik; teknologi komunikasi; media sosial; media online

\section{Information technology optimalization by government institution in public ABSTRACT communication activity}

Government PR plays an important role in the management of public communication. The challenge of the management of public communication today is rapid development of communication technology and flow of information in society. Government Institutions are required to optimize various forms of communication technology advancements in the management of public communication so that the public's needs for information on Government policies and programs can be conveyed properly. This research is conducted to determine the management of public communication at Government Institutions by optimizing communication technology by the standards written in Presidential Instruction No 9 of 2015 concerning the management of public communication. This study uses a mixed-method by combining quantitative and qualitative data and it is expected to meet the data requirements holistically to obtain an overview of the management of public communication in the Ministry, Institution and Local Government. The results of this study are the majority of respondents consisting of personnel from Ministries, Institutions and Office of the Ministry of Communication and Information at the provincial level have carried out public communication management by optimizing communication technology in the form of disseminating a single narrative and Government priority programs through online media and social media as well as conducting media monitoring and communication audits. Coordination between Government agencies in the management of public communication is also implemented. The recommendations given are the need to improve the quality and quantity of human resources, communication infrastructure; strategic planning needs to be done, prioritizing on interpersonal communication and strengthening the insititutions.

Keywords: Government public relations; management of public communication; communication technology;

Korespondensi: Centurion Chandratama Priyatna, S.S., M.Si., Ph.D. Universitas Padjadjaran. Jl. Raya Bandung-Sumedang Km.21, Hegarmanah, Jatinangor, Sumedang, Jawa Barat 45363. Email: centurion. priyatna@unpad.ac.id 


\section{PENDAHULUAN}

Derasnya arus informasi menjadi tantangan tersendiri bagi lembaga pemerintah, khususnya Humas pemerintahan, yang berperan penting dalam pengelolaan komunikasi publik. Dalam tugas pokok dan fungsinya, humas pemerintahan memiliki kewajiban untuk memastikan hak masyarakat atas informasi, meningkatkan partisipasi publik dalam kebijakan dan membantu jalannya pemerintah yang transparan (Idris, 2014), humas pemerintah memiliki peran yang penting dan strategis. humas pemerintah akan selalu dituntut untuk menghadapi perubahan di lingkungannya yang terjadi sangat cepat di tengah derasnya arus informasi dan perkembangan teknologi informasi (Risal, 2016).

Menurut Peraturan Menteri Dalam Negeri Pasal 1 ayat 3 No. 13 Tahun 2011, definisi humas pemerintah adalah aktivitas lembaga atau individu penyelenggara pemerintahan yang melakukan fungsi manajemen dalam bidang komunikasi dan informasi kepada publik pemangku kepentingan dan sebaliknya. Fungsi humas pemerintah yaitu memastikan keamanan perihal kebijakan pemerintah, memberikan pelayanan pada publik, dan menyebarluaskan informasi mengenai program dan kebijakan pemerintah (Ruslan, 2014). Selain itu humas pemerintah juga menjalankan peran sebagai komunikator dan mediator komunikasi untuk mendukung program pemerintah baik program jangka pendek maupun jangka panjang.

Melalui humas, pemerintah dapat menjelaskan program dan kebijakannya kepada publik sehingga muncul pemahaman serta partisipasi publik tentang program dan kebijakan tersebut. Selain itu humas berkewajiban untuk turut serta memantapkan program pemerintah dalam sebuah sistem politik agar menjadi semakin baik dan semakin mendukung pelaksanaan pemerintahan itu sendiri baik di tingkat Pusat, Provinsi, Kota, maupun Kabupaten. Kementerian Komunikasi dan Informatika yang menjalankan fungsi humas pemerintah melakukan koordinasi untuk perencanaan, penyiapan, dan pelaksanaan komunikasi publik terkait kebijakan dan program pemerintah (PRIndonesia, 2016). Hal ini sesuai dengan Instruksi Presiden No. 09 Tahun 2015. Tentang keterbukaan informasi publik. Lebih lanjut dijelaskan dalam Instruksi
Presiden tersebut jika Kementerian Komunikasi dan Informatika seharusnya berperan sebagai koordinator government public relations (GPR) yang mengambil peran sebagai Core Team dalam National Issues Management Structure.

Dirjen Informasi dan Komunikasi Publik, Kementerian Komunikasi dan Informatika, Ibu Niken Widiastuti menjelaskan dalam menjalankan fungsi humas pemerintah, ada dua kepentingan yang harus di perhatikan oleh Kementerian, Lembaga dan Pemerintah Daerah yakni kepentingan rakyat dan kepentingan global. Kepentingan rakyat terdiri atas informasi apa yang akan, sedang dan dikerjakan oleh pemerintah. Informasi tersebut harus disampaikan dengan cepat agar tidak membuat publik kebingungan. Oleh karena itu diperlukan koordinasi dari seluruh Kementerian, Lembaga dan Pemerintah Daerah, yang akan bermuara pada terbentuknya kepercayaan pemerintah dari masyarakat.

Humas pemerintah juga memiliki peran penting sebagai fasilitator komunikasi. Peran fasilitator komunikasi pada Humas berfungsi sebagai tempat keluar dan masuknya berbagai informasi dari dan untuk masyarakat (Siswanto \& Abraham, 2016).

Seluruh elemen kementerian, Lembaga dan Pemerintah Daerah harus peka akan kepentingan global, serta harus merubah pola pikir dan perilaku dari pola konsumsi menjadi pola produksi agar negara siap berkompetisi dengan negara lainya. Adanya persaingan di tengah kepentingan global menjadi salah satu tantangan terbesar bagi humas pemerintah dalam menghadapi tuntutan perkembangan zaman yang sangat cepat, terutama dalam perkembangan teknologi komunikasi dan informasi (Kominfo, 2016).

Hal yang tidak kalah pentingnya adalah bagaimana pola perilaku tersebut harus menjadi identitas bangsa dalam menciptakan sebuah Nation Branding yang terintegrasi dengan baik. Oleh karena itu seluruh elemen masyarakat harus terlibat atau berpartisipasi dalam menciptakan identitas bangsa tersebut. Langkah awal yang dapat dilakukan oleh Kementerian, Lembaga, dan Pemerintah Daerah dalam menciptakan identitas bangsa tersebut adalah mengelola komunikasi publik dengan baik. Komunikasi publik adalah pertukaran pesan dengan sejumlah orang yang berada dalam sebuah organisasi atau yang di luar organisasi secara tatap muka 
atau melalui media (Muhammad, 2008). Pengertian lain mengatakan bahwa komunikasi publik merupakan suatu ketrampilan berbicara di depan umum, bagaimana seorang pembicara menyampaikan pesan dan gagasan yang ingin diketahui oleh audience (Olii, 2010). Dapat disimpukan dari dua definisi tersebut diatas bahwa komunikasi publik memerlukan keterampilan komunikasi lisan dan tulisan agar pesan dapat disampaikan secara efektif dan efisien melalui media maupun tatap muka secara langsung.

Pengelolaan komunikasi publik merupakan perwujudan dari pemenuhan hak informasi bagi warga negara. Kementerian, Lembaga dan Pemerintah Daerah perlu bersamasama mengelola komunikasi publik untuk menciptakan "a well informed society" untuk memenuhi hak warga negara tersebut. Oleh karena itu, diperlukan tiga langkah strategis yang harus dilakukan oleh Kementerian, Lembaga dan Pemerintah Daerah. Yaitu: Pertama, perlu dibangun pengaturan sistem komunikasi, kedua pengembangan infrastuktur komunikasi, ketiga komunikasi publik.

Pada poin terakhir dalam langkah strategis tersebut yaitumengenai pengelolaan komunikasi publik, peraturan yang menaunginya telah lahir sejak tahun 2015, melalui Instruksi Presiden No 9 Tahun 2015 tentang pengelolaan komunikasi publik. Namun Instruksi Presiden ini tidak cukup jika tidak disertai dengan kesadaran dari Kementerian, Lembaga dan Pemerintah Daerah untuk berkomunikasi dengan masyarakat dan membangun komunikasi dua arah untuk mendapatkan masukan dari masyarakat. Hal lain yang harus dilakukan adalah meningkatkan kapasitas komunikasi dari Kementerian, Lembaga dan Pemerintah daerah itu sendiri. Menurut Direktur Kemitraan Komunikasi, dengan adanya Instruksi Presiden Nomor 9 Tahun 2015 tentang Pengelolaan Komunikasi Publik, diharapkan tidak ada lagi kegiatan komunikasi kehumasan yang mengedepankan ego sektoral.

"Diharapkan komunikasi pemerintah satu suara terkait kebijakan dan program prioritas pemerintah. Sehingga masyarakat terpenuh haknya untuk mendapatkan informasi pencapaian mengenai kebijakan dan kinerja pemerintah".

Instruksi Presiden Nomor 9 Tahun 2015,

Tabel 1 Peran dan tugas Kementerian, Lembaga, dan Pemerintah Daerah

(1)

Kementerian,

Lembaga dan

Pemerintah Daerah menyiapkan dan menyampaikan data beserta informasi terkait pelaksanaan tugas dan fungsi kepada Kementerian Komunikasi dan Informatika secara berkala
(2)

Kementerian

Komunikasi

dan Informatika melakukan kajian terhadap data dan informasi yang disampaikan , Lembaga dan Pemerintah Daerah serta melakukan media monitoring dan menganalisis konten media terkait dengan kebijakan dan program pemerintah;

\begin{tabular}{ll}
\hline (3) & $(4)$ \\
Kementerian & Kementerian \\
Komunikasi dan & Komunikasi \\
Informatika bersama & dan Informatika \\
Kementerian, & menyusun narasi \\
Lembaga dan & tunggal terkait \\
Pemerintah Daerah & dengan kebijakan dan \\
mengkoordinasikan & program pemerintah \\
perencanaan, & kepada publik sesuai \\
penyiapan, dan & arahan Presiden;
\end{tabular}

pelaksanaan

komunikasi publik terkait kebijakan dan program pemerintah;

(5)

Kementerian,

Lembaga dan

Pemerintah Daerah bersama Kementerian Komunikasi dan Informatika melaksanakan diseminasi informasi publik yang telah disusun melalui saluran komunikasi yang tersedia

Kementerian
Komunikasi
dan Informatika
melakukan
monitoring dan
evaluasi terhadap
pelaksanaan
komunikasi publik
secara berkala; dan
Menteri Komunikasi
dan Informatika
melaporkan ke
Presiden monitoring
dan evaluasi tersebut
setiap bulan.

Sumber: Instruksi Presiden no.9 Tahun 2015

Tentang keterbukaan informasi publik

menyebutkan bahwa kegiatan komunikasi publik pemerintah dilakukan secara sinergis. Masing-masing Kementerian, Lembaga dan Pemerintah Daerah memiliki peran dan tugas 
yang saling melengkapi untuk mendukung terlaksananya komunikasi public yang baik. Adapun pembagian peran tersebut dapat dilihat pada tabel 1 .

Kesadaran dari Kementerian, Lembaga dan Pemerintah Daerah untuk mengelola komunikasi publik menjadi elemen penting dalam lahirnya negara yang berdaulat, baik berdaulat secara virtual maupun berdaulat secara nyata. Kementerian, Lembaga dan Pemerintah Daerah bersinergi untuk mengkomunikasikan core competencies dari pemerintah dengan cara senantiasa mengkomunikasikan kepada publik seluruh aspek keunggulan, kelayakan dari sisi manajemen tata kelola pemerintahan, sumber daya yang dimiliki serta kebijakan atau program yang akan dan sedang dilaksanakan. Walaupun komunikasi interpersonal masih digunakan dalam impelementasi komunikasi publik dan seringkali menjadi hambatan (Saraswati, Romli, \& Nugraha, 2019). Dengan adanya perkembangan teknologi komunikasi yang sangat menunjang, tidak ada alasan lagi bagi Kementerian, Lembaga dan Pemerintah Daerah untuk tidak melakukan komunikasi dengan publiknya.

Perkembangan teknologi komunikasi perlu dioptimalkan dalam bidang pengelolaan komunikasi publik mengingat semakin derasnya arus informasi saat ini. Pengetahuan mengenai implementasi komunikasi publik, terutama dalam penggunaan teknologi komunikasi yang berbasis Internet, sangat diperlukan. Hasil riset yang dilakukan oleh Emarketer menyebutkan jumlah pengguna aktif telepon pintar di Indonesia pada tahun 2018 diperkirakan sebanyak lebih dari seratus juta orang angka tersebut akan terus bertambah dan jumlah tersebut menjadikan Indonesia dalam posisi keempat terbesar dalam jumlah pengguna telepon pintar di dunia (Rahmayani, 2015).

Fungsi humas pemerintah dalam menghadapi pesatnya perkembangan teknologi komunikasi, terutama dalam pelayanan publik, menurut Subiyakto pelayanan publik dapat ditingkatkan melalui teknologi komunikasi, dan hal tersebut telah menjadi tuntutan bagi praktisi public relations saat ini yang sudah memasuki era digital dan bukan lagi hanya menggunakan media konvensional dalam menyampaikan pesan (Trisnani, 2018). Cara publik mendapatkan informasi pun telah mengarah ke era digital termasuk pada kegiatan humas pemerintah. Adanya berbagai bentuk perhatian publik seperti munculnya trending topic melalui berbagai platform digital sebagai feedback dari masyarakat menjadi ciri perkembangan teknologi komunikasi yang sudah berpindah fokus tidak hanya pada media televisi atau media konvensional lainnya.

Kemajuan teknologi komunikasi tidak hanya dilihat dari kecepatan informasi yang didistribusikan melalui media sosial saja. Website juga menjadi bagian yang tak terpisahkan dari sebuah lembaga atau institusi termasuk lembaga dan institusi pemerintah dalam melayanani kebutuhan informasi publik. Kualitas website dalam pengelolaan komunikasi publik harus sangat diperhatikan. Kualitas layanan website Kementerian Komunikasi dan Informatika berdasarkan hasil penelitian yang menunjukkan bahwa Kementerian Komunikasi dan Informatika belum mempengaruhi kepuasan pengguna website berdasarkan pengukuran menggunakan WebQual 4.0 (Sanjaya, 2012).

Kualitas pengelolaan informasi melalui website juga diukur pada website resmi pemerintah daerah. Hasil penelitian lainnya menyatakan jika pengelolaan website resmi pemerintah daerah sebagian besar berada pada tingkat pertama atau pada tahap persiapan, hanya sebagian kecil yang dapat dikualifikasikan pada tingkat kedua yakni pematangan, bahkan untuk tingkat pematangan dan pemanfaatan pun belum tercapai dengan optimal (Sosiawan, 2017). Dari hasil penelitian tersebut dapat diketahui jika masih banyak lembaga Pemerintah yang menggunakan website dalam pengelolaan komunikasi publik hanya mencapai tahap webpresence atau hanya sebagai syarat bahwa Pemerintah Daerah tersebut memiliki website.

Penelitian mengenai pengelolaan komunikasi publik yang dilakukan ini penting dilakukan agar dapat memberikan rekomendasi khususnya bagi lembaga pemerintahan dalam melaksanakan pengelolaan komunikasi publik berdasarkan Instruksi Presiden No 9 Tahun 2015 dengan mengoptimalkan penggunaan teknologi komunikasi. Lahirnya media sosial membuat masyarakat dapat mengetahui setiap peristiwa yang terjadi di titik manapun di belahan bumi ini dalam sekejap. Sayangnya, Kementerian, Lembaga dan Pemerintah Daerah masih kalah dengan kecepatan berita hoax/ bohong yang beredar di media sosial terutama yang berkaitan dengan program pemerintah. 
Hal ini tentu berdampak buruk bagi legitimasi pemerintah, sehingga publik tidak lagi percaya dengan upaya dan pencapaian pemerintah pada saat ini. Tantangan yang semakin besar memerlukan kerja bersama dari seluruh elemen kementerian, lembaga dan pemerintah daerah untuk menyebarkan informasi kepada publik secara cepat, tepat, dan optimal.

Pengelolaan komunikasi publik yang optimal akan memberikan pemahaman yang baik bagi publik, seperti pada penelitian yang mengukur pengelolaan komunikasi publik di Kementerian Energi dan Sumber Daya Mineral yang dijelaskan (Ramadani, 2019). Hasil dari penelitian tersebut menunjukkan bahwa implementasi kebijakan mengenai pengelolaan komunikasi publik berdampak positif pada masyarakat karena mereka dapat menerima informasi terkait dengan kebijakan dan program di Kementerian Energi dan Sumber Daya Mineral secara lebih mudah dengan adanya fasilitas media sosial dan juga website Kementerian Energi dan Sumber Daya Mineral. Selain itu juga, implementasi Standard Operating Procedure dalam Instruksi Presiden No 9 Tahun 2019 mengarahkan lembaga pemerintah agar memberikan informasi yang netral dan jelas pada publik

Berdasarkan latar belakang penelitian di atas, penelitian pengelolaan komunikasi publik ini dilakukan untuk mengetahui pengelolaan komunikasi publik pada lembaga pemerintah dengan mengoptimalkan teknologi komunikasi sesuai dengan standar yang tertulis pada Instruksi Presiden No 9 Tahun 2015 tentang pengelolaan komunikasi publik.

\section{METODE PENELITIAN}

Penelitian ini menggunakan mix method dengan memadukan data kuantitatif dan kualitatif. Pemilihan mix method didasarkan pada kebutuhan data evaluasi yang diperlukan dalam proses penelitian ini. Penggunaan mix method dalam penelitian ini diharapkan dapat memenuhi kebutuhan data yang diperlukan secara holistic agar diperoleh gambaran pengelolaan komunikasi publik di Kementerian, Lembaga dan Pemerintah Daerah. Selain itu, pemilihan mix method dengan harapan saling melengkapi data kuantitaif dengan kualitatif ataupun sebaliknya keurangan di data kualitatif dilengkapi dengan data kuantitatif.
Oleh karena itu diperlukan instrumen yang mendukung untuk mendapatkan gambaran data di pada populasi dan sampel penelitian. Implementasi mix method dalam evaluasi pengelolaan komunikasi publik akan dikembangkan menjadi 3 teknik pengumpulan data, diantaranya: Pertama, Metode Survei. Metode survei pada evaluasi pengelolaan komunikasi publik menggunakan angket. Angket dibagikan kepada seluruh Kementerian, Lembaga dan Dinas Komunikasi dan Informatika tingkat Provinsi di seluruh Indonesia. Adapun untuk mempermudah distribusi dan pengisian angket, peneliti menggunakan google form dimana link dari google form tersebut dibagikan melalui group WhatsApp dan email dari masingmasing pejabat kementerian, lembaga dan dinas kominfo.

Kedua, Metode Rapid Apraisal. Metode rapid apraisal merupakan metode yang tepat untuk menggali data yang bersifat kualitatif, dimana rapid apraisal ini dirancang untuk mendapatkan informasi yang mendalam mengenai pengelolaan komunikasi publik, dalam hal ini pejabat di Kementerian, Lembaga dan Dinas Komunikasi dan Informatika, menjadi objek wawancara dengan menggunakan daftar pertanyaan yang sifatnya terbuka. Peran peneliti dalam menggali jawaban dari informan sangat diperlukan, hal ini dikarenakan peneliti merupakan instrument utama dalam penelitian kualitatif dikarenakan kemampuan menggali permasalahan melalui jawaban informan akan menghasilkan data yang mendalam.

Ketiga, Metode participatory Apraisal. Metode participatory dipilih dalam penelitian pengelolaan komunikasi publik untuk mendukung kedalaman data yang akan digali. Dimana dalam teknik pengambilan data di lapangan peneliti akan menjadikan pejabat di Kementerian, Lembaga dan Dinas Komunikasi dan Informatika sebagai subjek. Peneliti melakukan Focus Group Discussion dimana informan yang terpilih adalah orang yang menangani secara langsung komunikasi publik sehingga akan diperoleh data mengenai pengelolaan komunikasi publik yang lebih proporsional dan jelas. Selain itu penelitian ini juga ditunjang dengan penggunaan dokumendokumen pendukung serta buku-buku yang digunakan untuk memperkuat analisis dalam laporan penelitian pengelolaan komunikasi publik. 


\section{HASIL DAN PEMBAHASAN}

Kegiatan yang dilakukan untuk melayani kepentingan umum dapat dikategorikan dalam komunikasi publik. Program-program dalam komunikasi publik menggunakan komunikasi untuk menginformasikan atau mempersuasi, membangun hubungan, dan untuk mendorong dialog terbuka dalam organisasi atau komunitas terhadap solusi jangka panjang. Hal ini dilakukan dengan menyusun pesan yang sukses melalui penerapan penelitian, teori, pengetahuan teknis, dan prisip desain suara.

Komunikasi publik didefinisikan sebagai kegiatan dan strategi komunikasi yang ditujukan kepada khalayak sasaran (Dijkzeul \& Moke, 2005). Adapun tujuan komunikasi publik adalah untuk menyediakan informasi kepada khalayak sasaran dan untuk meningkatkan kepedulian dan mempengaruhi sikap atau perilaku khalayak sasaran. Singkatnya, komunikasi publik adalah alat strategis yang terdiri dari penggunaan berbagai media dalam kampanye diseminasi informasi yang komprehensif untuk menyampaikan pesan tertentu kepada khalayak tertentu. Apabila dibandingkan, komunikasi interpersonal atau komunikasi kelompok dengan komunikasi publik maka komunikasi publik merupakan jenis komunikasi yang bersifat konsisten, formal, serta berorientasi pada tujuan.

Hasil penelitian ini akan memberikan gambaran bagaimana kementerian, lembaga dan Dinas Komunikasi dan Informatika Tingkat Provinsi dalam implementasi pengelolaan komunikasi publik. Hasil penelitian ini merupakan perpaduan data kuantitatif dan data kualitatif, sehingga akan memberikan gambaran secara lebih mendalam bagaimana posisi pengelolaan komunikasi publik saat ini, kendala, dan langkah-langkah strategis yang dapat disiapkan sebagai upaya pengeloaan komunikasi publik. Berikut adalah data mengenai pengelolaan komunikasi publik, dapat dilihat pada gambar 1 .

Berdasarkan pada gambar 1, sebanyak 95,2\% responden menyatakan paham akan Instruksi Presiden No. 9 Tahun 2015. Tingginya angka pemahaman responden menunjukan bahwa sosialisasi tentang Instruksi Presiden No 9 Tahun 2015 dilaksanakan secara efektif. Responden yang terdiri dari pegawai Kementerian, Lembaga dan Dinas

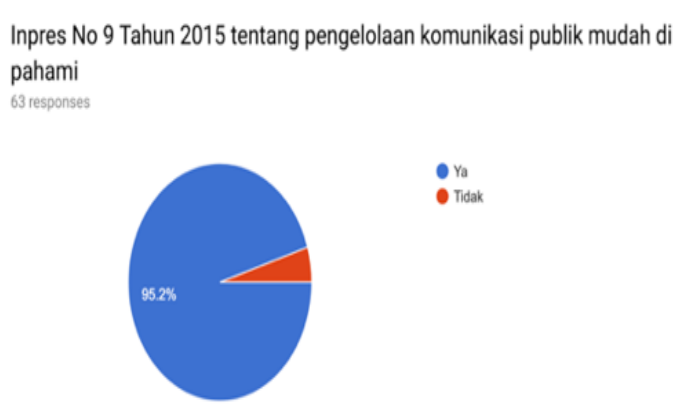

Inpres № 9 Tahun 2015 mempermudah pengelolaan komunikasi publik 63 responses

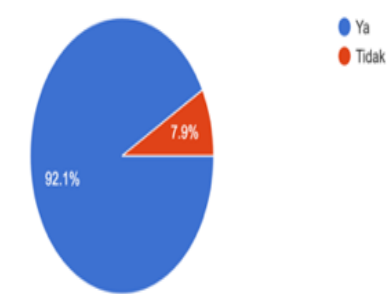

\section{Gambar 1 Pemahaman Tentang Instruksi Presiden No. 9 Tahun 2015}

Sumber : Hasil Penelitian, 2018

Kominfo tingkat provinsi di seluruh Indonesia, diharapkan dapat mengimplementasikan kebijakan pengelolaan komunikasi publik. Pemahaman responden menjadi sangat penting untuk diperhatikan. Staf merupakan sumber yang paling penting dalam melaksanakan kebijakan (Ramadani, 2019). Selain itu, tugas dan wewenang pejabat humas memiliki posisi yang sangat krusial dalam sebuah lembaga mulai dari melakukan pengembangan, implementasi, dan evaluasi berbagai program serta kebijakan sehingga pada akhirnya dapat menghasilkan tingkat pengertian yang tinggi antara organisasi dengan publiknya (Ratnasari, Rahmat, \& Prastowo, 2018).

Pemahaman yang perlu diperhatikan oleh pelaksana pengelolaan komunikasi publik sesuai dengan Instruksi Presiden No 9 Tahun 2015 adalah data dan informasi yang disampaikan pada Kementerian Komunikasi dan Informatika terkait dengan tugas dan fungsinya secara berkala, kemudian melalui berbagai saluran komunikasi menyebarluaskan kebijakan dan program pemerintah pada publik secara tepat, cepat, efektif dan objektif kepada masyarakat agar dapat dengan mudah dimengerti (Trisnani, 2018). 
Sebanyak 92,1 \% responden menyatakan bahwa Instruksi Presiden No. 9 Tahun 2015 dapat Memudahkan Pengelolaan Komunikasi Publik. Berdasarkan data tersebut, Instruksi Presiden No. 9 Tahun 2015 dapat membantu menjalankan tugas Humas Pemerintahan untuk menginformasikan segala hal mengenai kebijakan pemerintah dan pelayanan publik termasuk transparansi dan prosedur dalam pelayanan publik (Sjoraida \& Gemiharto, 2014).

Adanya Instruksi Presiden No 9 Tahun 2015 dapat menjadi salah satu arahan yang tepat dalam melakukan pengelolaan komunikasi publik sebagai salah satu upaya untuk mengoptimalkan strategi komunikasi. Kegiatan Humas pada sebuah lembaga khususnya lembaga pemerintah tidak bisa terlepas dari strategi komunikasi (Sonia, 2013). Humas diperlukan untuk menjaga reputasi dan citra lembaga serta menjadi salah satu penentu terpenting dalam kelangsungan suatu lembaga secara positif sehingga pemerintah harus memiliki tenaga Humas yang mumpuni dalam melakukan kegiatannya.

Berdasarkan pada gambar 2, diketahui sebanyak $85,7 \%$ responden menyatakan sudah
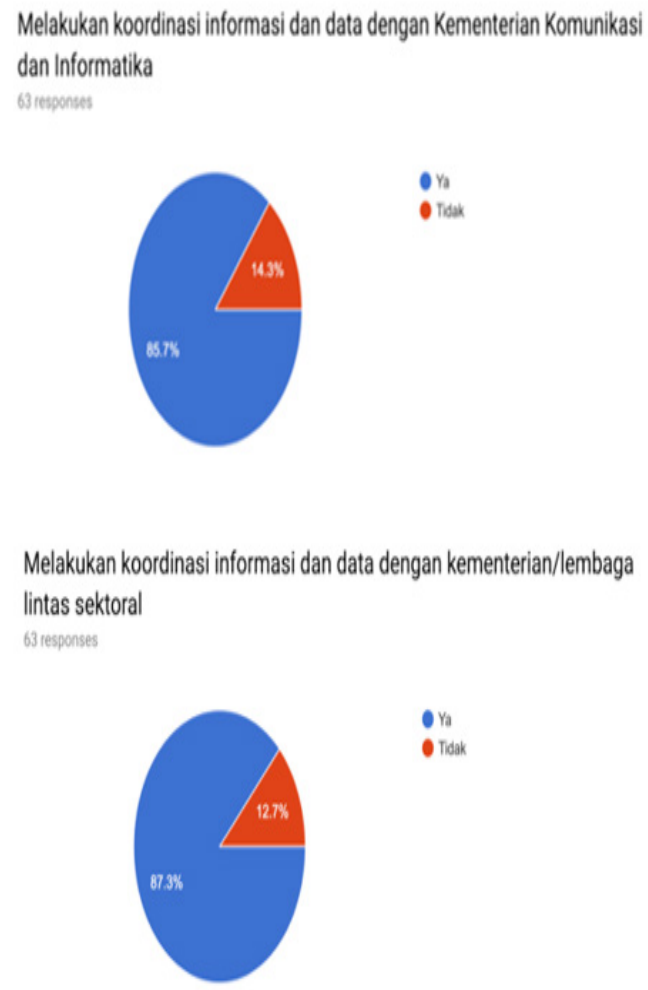

Gambar 2 Koordinasi Lembaga

Sumber : Hasil Penelitian, 2018 melakukan koordinasi dengan Kementerian Komunikasi dan Informatika dalam melakukan pengelolaan komunikasi publik. Hal ini telah sesuai dengan isi dari Instruksi Presiden No 9 Tahun 2015 yang berfokus pada koordinasi antara berbagai Lembaga pemerintah dengan Kemkominfo agar informasi yang disampaikan oleh Pemerintah pada publik satu suara sehingga tidak terjadi miss informasi yang disampaikan pada publik.

Berdasarkan data tersebut, diketahui bahwa sebanyak $87,3 \%$ responden menyatakan sudah melakukan koordinasi dengan Kementerian atau Lembaga lintas sektoral. Hal ini menunjukan koordinasi yang dilakukan dalam mengelola komunikasi publik tidak hanya dilakukan dengan Kementerian Komunikasi dan Informatika namun juga dengan lembaga lain yang terkait dengan pengelolaan komunikasi puhblik. Koordinasi ini dilakukan untuk mencapai tujuan dari Instruksi Presiden No. 9 Tahun 2015 yakni agar penyampaian setiap setiap kebijakan dan program pemerintah secara lintas sektoral dan lintas daerah kepada publik dilakukan secara cepat dan tepat.

Komunikasi publik merupakan usaha memfasilitasi masyarakat dengan informasi publik terkait kebijakan program dan kegiatan pemerintah yang sudah, sedang dan akan dilakukan (Indarto, 2018). Hal ini merupakan hal yang penting bagi kedua belah pihak, baik itu Pemerintah dan masyarakat itu sendiri, upaya ini dilakukan agar jurang antara pemerintah dan masyarakat tidak melebar, sehingga diperlukan upaya dalam bentuk strategi komunikasi yang dilakukan oleh Pemerintah untuk meminimalisir hal tersebut.

Berdasarkan pada gambar 3, sebanyak $84,1 \%$ responden telah melakukan penyusunan dan penyebarluasan narasi tunggal. Jika diintegrasikan dengan data sebelumnya, keberadaan koordinasi antara Kementerian Komunikasi dan Informatika dengan lembaga terkait telah sesuai dalam menyusun dan menyebarluaskan narasi tunggal sesuai dengan arahan Presiden.

Sebanyak 38,2\% responden menyusun narasi tunggal setiap hari dan kemudian pada urutan kedua intensitas tertinggi dalam menyusun konten narasi tunggal adalah satu bulan sekali yakni sebanyak 32,7\% dari jumlah responden. Data ini menunjukan bahwa pengelola komunikasi publik telah menyusun 
Menyusun dan menyebarluaskan narasi tunggal

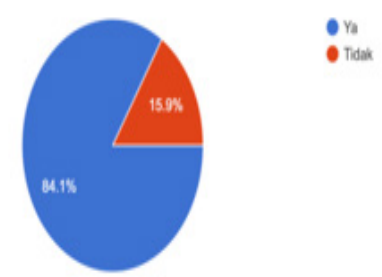

Intensitas menyusun konten narasi tunggal
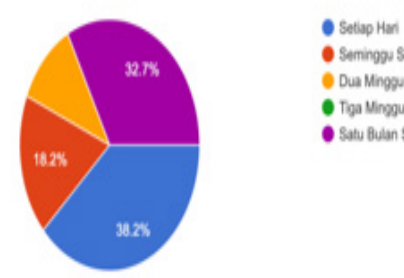

- Saringor Sekell

- Dua Mngos Secka

- Satu Buan Selal

Menyebarkan narasi tunggal melalui media online 63 responses

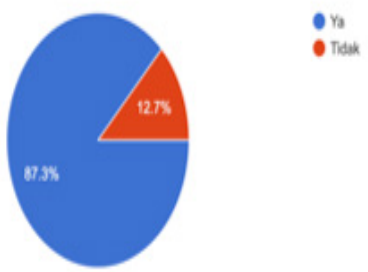

Gambar 3 Narasi Tunggal

Sumber : Hasil Penelitian, 2018

konten narasi tunggal secara konsisten.

Sebanyak $87,3 \%$ responden telah menyebarkan narasi tunggal pada publik melalui media online.Penggunaan media dalam menyampaikan pesan pada publik sangat penting. Gangguan atau noise dapat terjadi pada media penyampai pesan khususnya yang disampaikan pada publik secara luas (Nurrohim \& Anatan, 2009). Situasi pada saat penyampaian pesan juga sangat penting untuk diperhatikan sehingga perlu diperhatikan pemilihan media.

Pemilihan media online sebagai sarana untuk menyebarkan konten narasi tunggal sangat tepat. Saat ini masyarakat memilih media online yang kredibel dalam mencari informasi. Selain itu pemilihan media online dipengaruhi oleh karakteristiknya yang dapat memberikan informasi yang cepat dan akurat bagi publik sehingga dapat memenuhi kebutuhan informasi masyarakat. Era digital telah membawa masyarakat dalam berbagai kemudahan khususnya dalam mencari informasi (Setiawan, 2017). Akses informasi yang difasilitas oleh teknologi digital telah memudahkan berbagai kalangan dalam beraktivitas yang dapat dilakukan secara bebas dan terkendali.

Penyebaran informasi dalam pengelolaan komunikasi publik tidak hanya dilakukan pada konten narasi tunggal, namun juga pada program prioritas melalui media online, yakni sebanyak $88,9 \%$ responden menyebarluaskan program prioritas melalui media online.

Mayoritas pelaksana komunikasi publik telah menyebarluaskan informasi program pada publik melalui media online. Langkah ini sudah sangat tepat ditengah kondisi masyarakat saat ini yang terhubung setiap hari dengan Internet sebagai sarana media penyampai informasi. Terlebih jika dilihat dari karakteristiknya, Internet tidak terbatas pada wilayah geografis dan bisa diperoleh secara real time atau sesuai dengan waktu peristiwa terjadi. Hal ini menjadi tantangan bagi humas pemerintah untuk menyebarluaskan informasi termasuk berbagai program Pemerintah secara cepat untuk memenuhi kebutuhan informasi publik dalam real time.

Berdasarkan pada gambar 4, sebanyak $95,2 \%$ responden menyebarkan narasi tunggal melalui media sosial. Media sosial adalah media yang tepat untuk digunakan sebagai sarana dalam penyebaran narasi tunggal oleh lembaga pemerintah. Di era digital saat ini, media sosial bukan hanya berfungsi sebagai sarana komunikasi antar pribadi namun lebih dari itu, media sosial sangat mudah digunakan sebagai sarana penyebaran informasi di semua bidang (Fitriani, 2017).

Penelitian lainnya menyatakan jika masyarakat modern saat ini memilih media online, termasuk media sosial di dalamnya, dalam mencari informasi (Nurkinan, 2017). Dari hasil penelitian tersebut juga dinyatakan jika alasan publik memilih media sosial dalam memperoleh informasi adalah dari segi waktu, yaitu kecepatan perolehan informasi baik dalam bentuk teks, foto ataupun video. Hal ini menunjukan adanya aspek visual yang menarik pada penyajian informasi melalui media sosial dibandingkan dengan media konvensional.

Bahkan individu akan lebih mudah berinteraksi dalam berbagai forum yang terdapat pada media sosial (Nurkinan, 2017). Asumsi, 
Menyebarluaskan informasi dan data program prioritas kementerian/lembaga melalui media online: as inomest

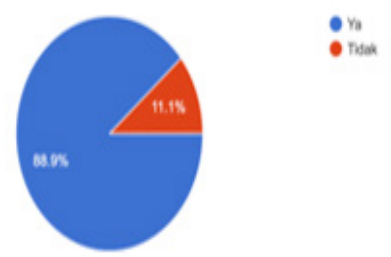

Menyebarkan narasi tunggal melalui media sosial 63 responses

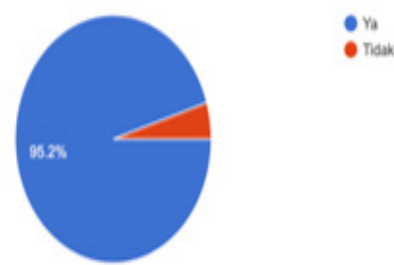

Menyebarkan narasi tunggal melalui grup komunikasi 63 erepones

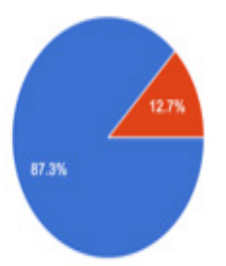

r

\section{Gambar 4 Menyebarluaskan Informasi melalui Media Online}

Sumber : Hasil Penelitian, 2018

emosi dan kepercayaan atau trust akan lebih mudah terbangun melalui interaksi pada media sosial karena adanya peluang untuk memberikan komentar secara langsung dan memberikan pendapat mengenai suatu isu terutama yang berhubungan dengan pemerintahan. Masyarakat yang sebelumnya cenderung memiliki jarak yang jauh untuk sekedar memberikan aspirasi pada lembaga pemerintah, akan lebih mudah menyampaikan pendapatnya melalui media sosial.

Berbagai penelitian terdahulu telah menjelaskan bahwa media sosial dapat membantu memperbaiki komunikasi antara lembaga pemerintah dengan masyarakat. Salah satunya hasil penelitian yang menjelaskan jika Pemerintah Kota Bandung berhasil menggunakan media sosial untuk aktivitas komunikasi Pemerintah Daerah, kualitas pelayanan komunikasi diperbaiki melalui penggunaan media sosial dan melalui interaksi yang dibangun oleh Pemerintah melalui media sosial, sehingga permasalahan yang ada di daerah dapat dipecahkan satu per satu (Munandar \& Suherman, 2016).

Penelitian lainnya dilakukan untuk mengukur efektivitas penggunaan media sosial sebagai media informasi bagi publik. Hasilnya, lebih dari $60 \%$ taman nasional di Finlandia dan Afrika Selatan yang memiliki aktivitas media sosial seperti Twitter dan Instagram memiliki potensi untuk turut serta memberikan informasi tentang pelestarian alam (Tenkanen et al., 2017). Dari hasil penelitian tersebut bisa diketahui jika media sosial dapat membantu penyebaran informasi bukan hanya mengenai produk atau keterangan dari sebuah lembaga namun turut menginformasikan mengenai isu yang lebih luas cakupannya kepada masyarakat.

Berdasarkan data di atas menunjukan sebanyak $87,3 \%$ responden menyatakan telah melakukan penyebaran narasi tunggal melalui group komunikasi. Hal ini dilakukan dalam mewujudkan salah satu tujuan pelaksanaan Instruksi Presiden No 9 Tahun 2015 yakni, narasi tunggal disebarkan pada masyarakat dan disusun oleh Kementerian Komunikasi dan Informatika serta diintegrasikan dengan program Pemerintah terkait.

Penggunaan group komunikasi dalam menyebarkan narasi tunggal disesuaikan dengan karakteristik masyarakat saat ini yang tidak bisa lepas dari segala aspek digital termasuk dalam pemenuhan informasi. Faktor kedekatan interpersonal dan lingkungan sosial juga memengaruhi seseorang mendapatkan dan menyebarkan informasi (Rumata, 2017). Di mana group komunikasi berbasis teknologi yang di dalamnya juga terdapat interaksi dan juga kedekatan interpersonal dapat dijadikan media yang tepat dalam penyebaran informasi.

Sebanyak $85,7 \%$ responden melakukan media monitoring sebagai tahapan pengelolaan komunikasi publik. Berdasarkan data di atas, diketahui jika mayoritas responden telah melakukan media monitoring. Media monitoring penting dilakukan khususnya di tengah derasnya arus informasi melalui media sosial saat ini. Monitoring yang dilakukan pada media sosial dilakukan sebagai kontrol strategis dan responsif terhadap apa yang sedang terjadi di masyarakat. (Fan \& Gordon, 2014) menjelaskan 
Melakukan media monitoring

63 responses

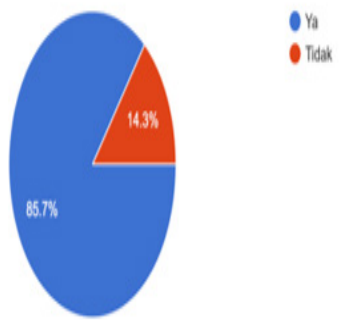

Intensitas melakukan media monitoring 55 eresponses

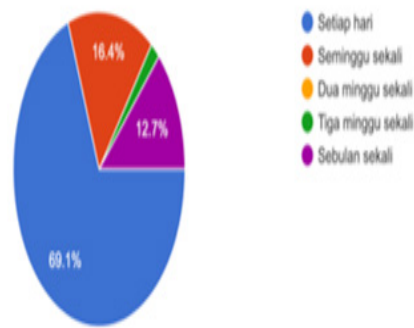

Melakukan audit/evaluasi pengelolaan Komunikasi publik 63 responses

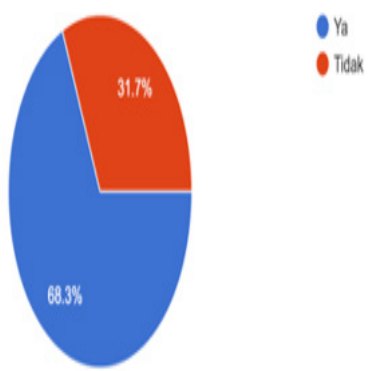

Intensitas melakukan audit/evaluasi pengelolaan komunikasi publik 50 responses

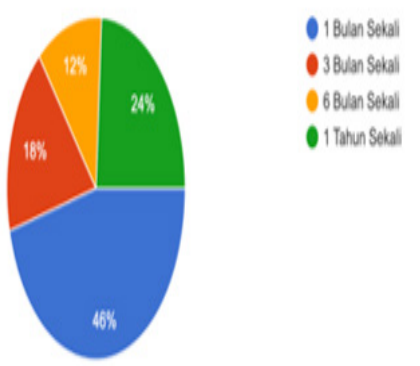

Sumber : Hasil Penelitian, 2018

Gambar 5 Media Monitoring dan Evaluasi jika media monitoring pada media sosial dapat menjadi cara yang cepat untuk mengidentifikasi ketidakpuasan publik terhadap sebuah kebijakan yang dibuat oleh Lembaga kemudian media monitoring juga berfungsi untuk memperbaiki masalah berdasarkan sumbernya.

Sebanyak 69,1\% responden melakukan media monitoring setiap hari, $16,4 \%$ melakukan media monitoring seminggu sekali dan $12,7 \%$ melakukan media monitoring satu bulan sekali. Mayoritas responden melakukan media monitoring setiap hari dan sisanya melakukan setiap satu minggu sekali serta satu bulan sekali. Intensitas media monitoring perlu diperhatikan, mengingat banyaknya informasi yang tersebar melalui media baik media online maupun konvensional terlebih pada era digital dengan adanya Internet sehingga mayoritas responden dalam melakukan media monitoring setiap hari sudah tepat dalam rangka melakukan fungsi controlling terhadap informasi dan isu yang ada di masyarakat.

Hal tersebut penting dilakukan mengingat adanya hubungan antara media monitoring dengan kinerja pegawai sebuah lembaga. Kekuatan pemantauan media memiliki efek penting pada perilaku korupsi dan kinerja bank kepemilikan pemerintah (Ho, Chen, Lin, \& Chi, 2016). Adanya hasil penelitian ini dapat menjadi acuan dalam melakukan intensitas media monitoring secara konsisten agar dapat berimbas positif pula pada kinerja lembaga pemerintah.

Sebanyak $68,3 \%$ responden melakukan audit komunikasi publik dan 31,7\% diantaranya tidak melakukan audit komunikasi publik. Kemudian ditemukan sebanyak 46\% melakukan audit komunikasi publik setiap satu bulan sekali, 24\% melakukan audit komunikasi publik setiap satu tahun sekali, $18 \%$ responden melakukan audit komunikasi publik setiap tiga bulan sekali dan $12 \%$ responden melakukan audit komunikasi setiap enam bulan sekali.

Audit komunikasi merupakan bagian penting pada proses pengelolaan komunikasi publik. Melalui audit komunikasi akan diperoleh data yang dapat dijadikan sebagai bahan pengembangan program selanjutnya. Terdapat lima unit analisis audit komunikasi berdasar pada Teori Informasi dan Organisasi. Dari lima unit analisis tersebut ditemukan bahwa faktor keterbukaan informasi baik secara vertikal atau horizontal memiliki peran besar dalam 
meningkatkan kinerja keberhasilan sebuah lembaga. Faktor lain adalah adanya peran teknologi komunikasi untuk menyederhanakan dan mempercepat penyampaian informasi. Baik disampaikan melalui media cetak atau media elektronik yang digunakan untuk mendukung organisasi. Audit komunikasi yang diterapkan di setiap organisasi akan meningkatkan kinerja organisasi (Ramadani, Lestari, \& Susilo, 2015).

Selain temuan tentang implementasi pengelolaan komunikasi publik di atas, berdasarkan hasil penelitian, diketahui terdapat beberapa hal yang perlu diperhatikan dalam pengelolaan komunikasi publik yang berdasar pada Instruksi Presiden No 9 Tahun 2015, salah satunya adalah adanya beberapa lembaga Pemerintah yang mengalami kesulitan mengumpulkan data informasi sebagai dasar dalam pengelolaan komunikasi publik. Hal ini harus menjadi perhatian bagi Kementerian Komunikasi dan Informatika untuk meningkatkan pengetahuan bagi pengelola komunikasi publik sehingga penyebarluasan informasi sebagai tugas mulia untuk menciptakan masyarakat yang well informed dapat tercapai.

Kemudian, perkembangan teknologi komunikasi merupakan peluang akses untuk menyebarluaskan informasi dengan cepat dan tepat. Perkembangan teknologi komunikasi harus diterapkan secara merata mengingat adanya konsekuensi sebagai negara kepulauan yakni keterjangkauan jaringan komunikasi harus sampai pada level desa.

Hal lain yang perlu diperhatikan dalam melakukan integrasi komunikasi pada setiap tahapan pengelolaan komunikasi publik adalah perlu dibangun keterikatan antara Kementerian, Lembaga, dan Dinas Komunikasi dan Informatika bersama masyarakat melalui berbagai pendekatan komunikasi yang mendekatkan diri dengan publik. Sehingga pada akhirnya Kementerian Komunikasi dan Informatika sebagai koordinator pengelolaan komunikasi publik dapat menjalankan fungsinnya sebagai faslitator komunikasi dengan mendengarkan aspirasi dari kementerian lain, lembaga dan dinas komunikasi dan informatika di daerah.

Terakhir, dalam pengelolaan komunikasi publik perlu adanya standarisasi kompetensi sumber daya manusia di level kementerian, lembaga dan dinas komunikasi dan informatika di provinsi sebagai pengelola komunikasi publik perlu ditingkatkan.

Komunikasi publik adalah komunikasi yang melibatkan pertukaran pesan dari organisasi ke publik. Baik publik internal perusahaan maupun publik eksternal perusahaan. Perusahaan dalam berkomunikasi dengan publiknya dapat melakukannya secara langsung atau melalui media. Komunikasi publik didasarkan pada kebutuhan suatu organisasi untuk berkoordinasi dengan publiknya dan menciptakan sinergi dalam berkomunikasi dengan publik internal maupun eksternal (Goldhaber, 1993).

Menurut Daniel dan Spiker, komunikasi terhadap publik internal termasuk berbagai aspek dalam komunikasi organisasi dari fungsi manajemen dan sumber daya manusia. Yaitu orientasi, keamanan, kompensasi dan benefit, pelatihan dan pengembangan serta perbaikan moral pekerja dan kepuasan bekerja (Goldhaber, 1993).

Berbeda cakupannya dengan komunikasi publik eksternal. Komunikasi publik eksternal mencakup: (1) Komunikasi dalam menciptakan citra organisasi; (2) Komunikasi mengenai isu dan opini publik; (3) Komunikasi komersial yang mempromosikan output (barang atau jasa) sebuah organisasi (Goldhaber, 1993).

Komunikasi publik menjadi penting karena organisasi dipahami sebagai sistem terbuka yang memproses input (bahan baku, sumber daya alam dan manusia serta informasi) menjadi output yang dikirim kepada lingkungannya dan mempunyai dampak tersendiri seperti barang, jasa bahkan polusi (Goldhaber, 1993). Sebuah organisasi secara otomatis memberikan efek terhadap lingkungannya.

Maka dari itu seperti yang sudah dijelaskan pada bagian komunikasi organisasi peran buffer untuk melindungi inti organisasi dan boundary spanning sebagai tempat arus pertukaran informasi sangatlah penting supaya sebuah organisasi bisa bertahan antara lain dengan menjalankan komunikasi publik untuk merespon ketidakpastian lingkungan. Selain itu komunikasi publik juga bertujuan untuk menciptakan dan memperkuat citra organisasi di mata publik.

Sekilas komunikasi publik terlihat serupa dengan komunikasi diadik dan komunikasi kelompok kecil namun ada beberapa batasan yang membedakan antara komunikasi publik dengan komunikasi diadik dan kelompok 
kecil, diantaranya orientasi utama dalam komunikasi publik adalah sumber (pembicara). Pada komunikasi organisasi diadik dan kelompok kecil hubungan bersifat resiprokal antara sumber dengan penerima sedangkan dalam komunikasi organisasi publik lebih menekankan pada pembicara tentunya pada komunikasi publik pembicara/ speaker lebih mendominasi. Komunikasi publik mencakup sekelompok besar penerima yang dilibatkan. Dalam komunikasi diadik dan kelompok kecil tidak mencakup publik yang luas karena hanya terdiri tidak lebih dari tujuh anggota dan ketika ingin berkomunikasi dengan jumlah yang lebih banyak melalui tatap muka hal ini menjadi sulit dan tidak mungkin, maka perlu dipertimbangkan dengan komunikasi publik sehingga pembicara dapat mengakomodasi penerima pesan dengan jumlah yang lebih banyak (Goldhaber, 1993).

\section{SIMPULAN}

Kementerian, lembaga dan Dinas Komunikasi dan Informatika tingkat provinsi telah melakukan pengelolaan komunikasi publik dengan mengoptimalkan teknologi komunikasi dalam bentuk penyebaran narasi tunggal dan program prioritas pemerintah melalui media online dan media sosial. Dalam tahap controlling dilakukan media monitoring dan mayoritas responden melakukannya setiap hari, hal ini dilakukan untuk melihat perkembangan informasi di masyarakat yang terjadi sangat cepat setiap harinya. Evaluasi pengelolaan komunikasi publik dilakukan melalui audit komunikasi dimana sebagian besar responden melakukan audit komunikasi setiap satu bulan sekali.

Berdasarkan hasil penelitian di atas, terdapat koordinasi antar lembaga pemerintah dengan menggunakan berbagai saluran komunikasi yang telah diintegrasikan secara terpusat dan dikelola oleh Kementerian Komunikasi dan Informatika dalam bentuk website, WhatsApp Group, dan juga berbagai kanal media sosial yang teringrasi. Integrasi tersebut dilakukan untuk melakukan koordinasi dalam ruang lingkup humas pemerintah melalui dunia maya sebagai bentuk mengoptimalkan teknologi komunikasi apabila informasi semua di-share di media digital maka kebutuhan informasi masyarakat akan terpenuhi.

Hasil penelitian ini dijadikan dasar dalam pemberian rekomendasi kepada pelaksana pengelola komunikasi publik Kementerian Komunikasi dan Informatika, diantaranya adalah: Diperlukan upaya kolaborasi dan koordinasi dari berbagai elemen di kementerian, lembaga dan Dinas Komunikasi dan Informatika di seluruh Indonesia. Dalam pengelolaan komunikasi publik perlu ditunjang dengan kuantitas dan kualitas sumber daya manusia yang memiliki kompetensi mengelola komunikasi publik, agar tercipta partisipasi publik dan terbentuknya kepercayaan publik pada pemerintah.

Selain itu, perlu dirancang dan dibangun pengembangan infrastruktur komunikasi sampai ke level pedesaaan, sehingga pengelolaan komunikasi publik tidak terkendala lemahnya sinyal dan diseminasi informasi dapat dilakukan sampai ke penjuru nusantara. Kemudian, perlu dilakukan perencanaan strategi dan taktik pengelolaan komunikasi publik diutamakan melalui komunikasi interpersonal sehingga mampu mempersuasi masyarakat secara interaktif.

Upaya kerjasama strategis yang bersifat dua arah dan melibatkan seluruh elemen pengelola komunikasi publik, perlu dirancang di masa depan untuk menunjang pengelolaan komunikasi publik. Penguatan kelembagaan di dalam kementerian, lembaga dan dinas komunikasi dan informatika perlu dilakukan, terutama dalam hal tata kelola fungsi humas serta dinas komunikasi dan informatika dalam pengelolaan komunikasi publik, supaya tidak ada tumpang tindih pekerjaan dan akan melahirkan principle of one voice di pemerintahan. Dan terakhir, perlu adanya rancangan pola rekrutmen sumber daya manusia di kementerian, lembaga dan dinas komunikasi dan informatika untuk mendapatkan orang-orang terbaik di bidang komunikasi publik. Bagi sumber daya manusia pengelola komunikasi publik yang sudah ada di kementerian, lembaga dan dinas komunikasi dan informatika, pelatihan/workshop sebaiknya diberikan untuk meningkatkan kapabilitas.

\section{DAFTAR PUSTAKA}

Dijkzeul, D., \& Moke, M. (2005). Public communication strategies of international humanitarian organizations. International Review of the Red Cross, 87(860), 673-691. https://doi.org/10.1017/ 
S1816383100184504

Fan, W., \& Gordon, M. D. (2014). The power of social media analytics. Communications of the ACM. 57 (6), 74-81. https://doi. org/10.1145/2602574

Fitriani, Y. (2017). Analisis pemanfaatan berbagai media sosial sebagai sarana penyebaran informasi bagi masyarakat. Paradigma - Jurnal Komputer Dan Informatika. 19(2), 148-152. https://doi. org/10.31294/P.V19I2.2120

Goldhaber, G. . (1993). Organizational communication. New York: Mc Graw-Hill.

Ho, P. H., Chen, H. K., Lin, C. Y., \& Chi, C. W. (2016). Does monitoring by the media improve the performance of government banks? Journal of Financial Stability. 22(C), 76-87. https://doi.org/10.1016/j. jfs.2015.12.006

Idris, I. K. (2014). Peran humas pemerintah di era keterbukaan informasi. Jurnal Universitas Paramadina, 11(6), 1147-1163. http:// journal.paramadina.ac.id/index.php/upm/ article/view/50

Rahmayani, I. (2015). Indonesia raksasa teknologi digital Asia. KOMINFO. Retrieved October 24, 2019. URL: https:// kominfo.go.id/content/detail/6095/ indonesia-raksasa-teknologi-digital-asia/0/ sorotan media

Kominfo. (2016). Humas pemerintah harus jadi andalan. Retrieved October 24, 2019, from https://www.kominfo.go.id/content/ detail/8258/humas-pemerintah-harus-jadiandalan/0/berita satker

Nurkinan.(2017).Dampakmedia onlineterhadap perkembangan media konvensional. Jurnal Politikom Indonesiana, 2(2), 2842. https://journal.unsika.ac.id/index.php/ politikomindonesiana/article/view/962

Nurrohim, H., \& Anatan, L. (2009). Efektivitas komunikasi dalam organisasi. Jurnal Manajemen Maranatha, 7(4), 11-20. Retrieved from https://media.neliti.com/ media/publications/112652-ID-efektivitaskomunikasi-dalam-organisasi.pdf

PRIndonesia.(2016). Karutmarut prpemerintah. Retrieved October 24, 2019, from https:// www.prindonesia.co/detail/358/KarutMarut-PR-Pemerintah

Ramadani, D., Lestari, P., \& Susilo, M. E. (2015). Audit komunikasi organisasi
Wahana Lingkungan Hidup Indonesia (Walhi) Yogyakarta. Jurnal ASPIKOM, 2(4), 282-290. https://doi.org/10.24329/ aspikom.v2i4.78

Ramadani, T. (2019). Implementasi kebijakan Pengelolaan komunikasi publik di Kementrian Energi dan Sumber Daya Mineral. Jurnal Borneo Administrator, 15(1), 1-18. https://doi.org/10.24258/jba. v15i1.369

Ratnasari, E., Rahmat, A., \& Prastowo, F. A. A. (2018). Peran humas perguruan tinggi negeri badan hukum dalam implementasi kebijakan keterbukaan informasi. PRofesi Humas: Jurnal Ilmiah Ilmu Hubungan Masyarakat, 3(1), 21-38. https://doi. org/10.24198/prh.v3i1.14034

Risal, M. (2016). Kearifan lokal dalam pembentukan daerah otonomi baru di era otonomi daerah. Jurnal Administrative Reform, 4(2), 106-126. Retrieved from http://e-journals.unmul.ac.id/index.php/ JAR/article/view/597/547

Rumata, V. M. (2017). Perilaku pemenuhan dan penyebaran informasi publik bagi masyarakat kota dan desa. Jurnal Penelitian Komunikasi, 20(1), 91-106. https://doi. org/10.20422/jpk.v20i1.146

Ruslan, R. (2014). Manajemen public relations $\&$ media komunikasi. In Manajemen public relations \& media komunikasi. Jakarta: Kencana.

Sanjaya, I. (2012). Pengukuran kualitas layanan website Kementerian Kominfo dengan menggunakan Webqual 4.0. Jurnal Penelitian IPTEK-KOM, 14(1), 1-14.

Saraswati, E. J., Romli, R., \& Nugraha, R. (2019). Kegiatan Hubungan media pada Direktorat Komunikasi Publik di Universitas Padjadjaran. PRofesi Humas : Jurnal Ilmiah Ilmu Hubungan Masyarakat, 3(2), 202-218. https://doi.org/ISSN: 25413678

Setiawan, W. (2017). Era digital dan tantangannya. Seminar Nasional Pendidikan 2017.

Siswanto, B. D. L., \& Abraham, F. Z. (2016). Peran humas pemerintah sebagai fasilitator komunikasi pada Biro Humas Pemprov Kalimantan Selatan. Jurnal Penelitian Komunikasi, 19(1). https://doi. org/10.20422/jpk.v19i1.64 
Sjoraida, D. F., \& Gemiharto, I. (2014). Optimalisasi peran dan fungsi humas pemerintahan untuk meningkatkan partisipasi masyarakat dalam pembangunan di Jawa Barat. In Seminar Besar Nasional Komunikasi (pp. 743-751). Retrieved from http://digilib.mercubuana.ac.id/ manager/t!@file_artikel_abstrak/Isi_ Artikel_278168125038.pdf

Sosiawan, E. A. (2017). Evaluasi implementasi e-government pada situs web pemerintah daerah di Indonesia: Prespektif Content Dan Manajemen. Seminar Nasional Informatika.

Tenkanen, H., Di Minin, E., Heikinheimo, V., Hausmann, A., Herbst, M., Kajala, L., \& Toivonen, T. (2017). Instagram, Flickr, or Twitter: Assessing the usability of social media data for visitor monitoring in protected areas. Scientific Reports, 7(17615), 1-11. https://doi.org/10.1038/ s41598-017-18007-4

Trisnani. (2018). Implementasi e-government public relations sebagai peningkatan pelayanan informasi publik, di lingkungan Pemda Jawa Timur dan Nusa Tenggara Barat. Jurnal Komunikasi, Media Dan Informatika, 7(3), 165$175 . \quad$ https://www.researchgate.net/ publication/329535878_implementasi_egovernment_public_relations_sebagai_ peningkatan_pelayanan_publik_ dilingkungan_pemerintah_daerah_di_ jawa_timur_dan_nusa_tenggara_barat 